\title{
The Correlation of Body Morphological Size Toward the Body Weight of PO Steers and Heifers
}

\author{
J Efendy ${ }^{*}$, PW Prihandini and TA Sulistya \\ Loka Penelitian Sapi Potong, Jl. Pahlawan No. 2 Grati Pasuruan - East Java Province 67184, \\ Phone : 0343- 481131, Fax: 0343-481132, Indonesia \\ "Corresponding author email: jauhariefendy67@gmail.com
}

\begin{abstract}
The study was conducted to determine the correlation between the body morphology size of PO steers and heifers which kept in the group housing of Litbangtan Models. The materials of this study used 24 PO steers and heifers (each cow was 15 to 18 months old). The data were analyzed using descriptive statistics and correlation analysis. Due to the significant value, it stated that the body length and chest circumference influenced positively to the gain of the weight body of PO steers and heifers. The value of determination analysis $\left(\mathrm{R}^{2}\right)$ both PO steers and heifers was $92.70 \%$ and $86.80 \%$; It indicated that the gain of the body length size and chest circumference would increase the body weight. The result of calculation shown that the average of body weight of PO steers and heifers after having used two body morphological measurement (body length and chest circumference) was relativeely close to the real measurement. This phenomenon indicated that the body length and chest circumference had a close relationship with the body weight either in PO steers and heifers.
\end{abstract}

Key words: PO steers and heifers, body morphological size, body weight

Abstrak. Penelitian ini dilaksanakan untuk menentukan korelasi antara ukuran morfologi tubuh PO steers dan heifer yang dipelihara di kandang kelompok Litbangtan Model. Materi yang digunakan dalam penelitian ini adalah 24 PO steer dan heifer (masing-masing berumur 15 sampai 18 bulan). Data dianalisis menggunakan deskriptif statistik dan analisis korelasi. Berdasarkan nilai signifikan, dinyatakan bahwa panjang badan dan lingkar dada berpengaruh positif terhadap peningkatan bobot badan PO steer dan heifer. Nilai koefisien determinsasi $\left(R^{2}\right)$ PO steer dan heifer adalah $92,70 \%$ dan $86,80 \%$; mengindikasikan bahwa peningkatan ukuran panjang badan dan lingkar dada akan meningkatkan bobobt tubuh. Hasil perhitungan menunjukkan bahwa rataan bobot tubuh PO steer dan heifer setelah menggunakan dua ukuran morfologi tubuh (panjang badan dan lingkar dada) serupa dengan ukuran nyata. Fenomena ini menunjukkan bahwa panjang badan dan lingkar dada berkaitan erat dengan bobot tubuh pada PO steer maupun heifer.

Kata kunci: PO steer dan heifer, ukuran morfologi tubuh, bobot tubuh

\section{Introduction}

The beef cattle is one of the strategic commodities because it is the second source of animal protein after poultry. However, the national meat production can not meet the domestic consumer demand. Therefore, this condition will increase the import of meat and cattle from other countries, especially Australia, either the frozen meat or internal organ (Hartati et al., 2009).

On the other hand, the growth of beef cattle population in Indonesia tend to increase, reaching 11.8 million in 2008 or increased quantitatively by $3.04 \%$ per year, compared to
10.5 millions in 2004 (Direktorat Jenderal Peternakan, 2008). Beef cattle census in 2011 reported that the population of Indonesia beef cattle reached 14.805 millions. Furthermore, East Java province had 4.7 millions beef cattle dominated by PO (Litbang Deptan, 2011).

All characters of beef cattle are the reflection of a number of genes, whether appeared or not, so all information was observed from every beef cattle "genetic marker". In breeding activity, both direct measurement of the phenotypic appearance and the various markers (markers) were used to monitor either the introgression or the genome 
recombinant (Sarbaini, 2004). The external appearance was able to measure and use as the inherited characteristic gens with economic value (Wijono et al., 2007). Otoikhian et al., (2008) stated that the relationship between body measurements and body weight in West African Dwarf goats was $74.4 \%$.

Dalton (1980); Warwick et al. (1983) stated that the phenotypic appearance influenced the genetic factor, environmental factor, and both factors. According to Aryogi et al. (2005) environmental condition caused phenotypic response which was not suitable with the cattle gene. The morphological and growth characteristics would develop as the aging process and they would be influenced by various factors, especially feeding and health management. Climate factors, however did not give any negative effect. Furthermore, Wijono et al. (2006) found no significant relationship between the climate and growth; besides, beef cattle was naturally adaptable to tropical area. Burnham et al. (2000) reported that body weight gain and feed intake of heifers and steers from the age of 9-25 months showed no significant difference. It indicates that fluctuations in feed management on the same feed conditions will generate diversity for different growth, therefore the selection of morphology can be utilized in similar environmental conditions or conditions of the same body.

In order to obtain optimum beef cattle, the researcher needed an equipment to determine the simple and more realistic selection based on external appearance (morphology). Morphology is expected to use as the guide and to describe the inherited phenotypic characteristics. The weight of beef cattle could be variable along with high blade, body length and chest circumference and other measurable growing factors. The length and width of the crotch comprised the variables of body size. The study was implemented to estimate body weight of Bali cattle with determination coefficient of $82.9 \%$ (Rachma et al., 2009). The purpose of this study is to determine the correlation between the body morphology size toward the body weight of PO steers and heifers kept in the group housing of Litbangtan Model, The Beef Cattle Research Station.

\section{Materials and Methods}

The study was conducted in the group housing of "Litbangtan Model" The Beef Cattle Research Station. It started from April to August 2013. The material in this study used $24 \mathrm{PO}$ steers and heifers, (Each sample was from 12 steers and 12 heifers) at the age of 15 up to 18 months. They were kept in the group housing of Litbangan Model, The Beef Cattle Research Station. The feed was given in the form of concentrate by $7.5 \mathrm{~kg}$ per cattle per day in the morning around $6.30 \mathrm{am}$; forages were given twice a day in the morning, starting from 8 am and $1.30 \mathrm{pm}$ with total provision of $8.5 \mathrm{~kg}$ per cattle per day.

Weighing the body weight and measuring the body morphology size of beef cattle were done twice. Those activities were held on May 27, 2013 and August 15, 2013. The size of the measured body morphology included the body height, body length, chest circumference and the hip height. The researcher measured the body height vertically from the ground to the top of its back using a measuring stick. Meanwhile, the body length was measured from the shoulder point to the sitting bones by using a measuring ribbon (Awaludin and Panjaitan, 2010). The chest circumference was measured directly behind the body encircling blade using a measuring ribbon, the hip height measured vertically from the ground to the top of the hip bone by using a measuring stick. Body weight was weighed using a digital scale. The data were subject to descriptive analysis and multiple linear regression analysis using SPSS data processing program 16.0 version to determine the coefficient of correlation and determination. 


\section{Results and Discussion}

\section{The mean of body morphology size}

The morphology of PO steers and heifers comprised four measuring components namely body height $(\mathrm{BH})$, chest circumference (CC), body length (BL) and hip height $(\mathrm{HH})$. The means of body morphological measuring results are presented in Table 1.

The different measurement of chest circumference of PO steers and heifers had the highest addition than other body parts namely $11.2 \mathrm{~cm}$ and $7.6 \mathrm{~cm}$, respectively within 80 days (May $27^{\text {th }}$ to August $15^{\text {th }}$ 2013). Body lenght addition was $6.70 \mathrm{~cm}$ and $6.67 \mathrm{~cm}$ on PO steer and PO heifer, respectively. The bull had the relatively higher body morphology size and weight than cow ones. Similar to Chadijah (2012), body weight gain of Bali bulls was higher than cows in spite of the same $1 \%$ body weight concentrate feed and ad libitum forage treatment.

PO steers were heavier than PO heifers because of the stimulation of androgen hormones. As Kay and Housseman (1975) stated, the androgen hormone of bulls was able to stimulate their growth being the larger ones. Its existence also increased the concentration of insulin and the hormonal growth. Accordingly, the growth of secretion hormone would increase the average of the body weight gain, feed efficiency and protein content (levels of insulin and glucose in plasma) but it made the growth loss of fat tissue (Parakkasi, 1999).

\section{The correlation of body morphological size on} body weight

Coefficient value of body morphological size of PO steers and heifers could be as an indicator to determine the significant level between the various variables of body morphological size against the body weight (Table 2).

Due to the significant value, it indicated that the body length and the chest circumference brought positive effect toward the body weight gain of the PO steers and heifers. Hanibal (2008) reported that the chest circumference and body length were positively related with the body weight. Meanwhile, average body height and hip height did not automatically increase the weight but the two variables would increase along with the aging process (Abdullah et al., 2006).

The value of regression coefficient on PO steers body length was 2.454 indicated that every one centimeter length in PO steer body would increase the body weight around 2.545 $\mathrm{kg}$; but of their chest circumference, body height and hip height remained. Furthermore. the chest circumference variables with around regression coefficient of 2.117 indicated that every one centimeter in gain of those variables being able to increase by $2.117 \mathrm{~kg}$ of body weight in terms of body length, body height and hip height high fixed. Similarly, PO heifers with regression coefficient in the term of body length and chest circumference was around 2.160 and 2.560 .

Table 1. The mean of the body morphological size and the average daily gain (AVG) of PO steers and heifers

\begin{tabular}{|c|c|c|c|c|c|c|c|c|c|}
\hline \multirow{3}{*}{ Sex } & \multicolumn{8}{|c|}{ Body Morphology $(\mathrm{cm})$} & \multirow{3}{*}{$\begin{array}{c}\text { BWG } \\
(\mathrm{kg})\end{array}$} \\
\hline & \multicolumn{2}{|c|}{$\begin{array}{c}\mathrm{BH} \\
\text { measuring in- }\end{array}$} & \multicolumn{2}{|c|}{$\begin{array}{c}\mathrm{CC} \\
\text { measuring in - }\end{array}$} & \multicolumn{2}{|c|}{$\begin{array}{c}\mathrm{BL} \\
\text { measuring in - }\end{array}$} & \multicolumn{2}{|c|}{$\begin{array}{c}\mathrm{HH} \\
\text { measuring in - }\end{array}$} & \\
\hline & 1 & II & I & II & I & II & 1 & II & \\
\hline Steer & 118.00 & 122.80 & 135.90 & 147.10 & 116.50 & 123.17 & 126.60 & 130.50 & 39.19 \\
\hline Heifer & 117.80 & 120.50 & 137.70 & 145.30 & 119.30 & 126.08 & 127.30 & 130.30 & 33.38 \\
\hline
\end{tabular}

$\mathrm{BH}=$ Body height; $\mathrm{CC}=$ chest circumference; $\mathrm{BL}$ = body length; $\mathrm{HH}$ = hip height; $\mathrm{BWG}$ = body weight gain 
Table 2. The significant value of the body morphological size of PO steers and heifers toward the body weight

\begin{tabular}{|c|c|c|c|}
\hline Sex & $\begin{array}{l}\text { Variables of body morphological } \\
\text { size }\end{array}$ & $\mathrm{t}_{\text {calculate }}$ & Significant level value \\
\hline \multirow{4}{*}{ Steer } & Body length & 3.680 & 0.002 \\
\hline & Chest circumference & 2.816 & 0.011 \\
\hline & Body height & -1.186 & 0.250 \\
\hline & Hip height & 2.085 & 0.051 \\
\hline \multirow{4}{*}{ Heifer } & Body length & 3.297 & 0.004 \\
\hline & Chest circumference & 4.094 & 0.001 \\
\hline & Body height & -1.670 & 0.111 \\
\hline & Hip height & 1.982 & 0.062 \\
\hline
\end{tabular}

Analysis value of multiple correlation $(R)$ was quantity used as the basic calculation to determine the relationship among measurable variables of body weight. Sugiyono (2007) stated that the value of multiple correlation analysis in the range from 0 to 1 . The analysis value began from 0.00 to 0.19 showing the low correlation. Meanwhile. value started from 0.80 to 1.00 showing very high correlation. According to Table 2 and 3, the relationship among those variables, especially the body length and chest circumference of the body weight was very high.

Analysis of determination value $\left(R^{2}\right)$ indicated the correlation among measurable variables of body weight. The value $R^{2}$ of $P O$ steers and heifers was 0.927 and 0.868. It indicated that the increasing of body length. chest circumference. body height and hip height having given influence around $92.70 \%$ and $86.80 \%$ toward the body weight gain either on PO steers and heifers. Result by Tadesse et al. (2012) showed that the value of $R^{2}$ Abergelle goat for relationship between chest circumferences. body length and shoulder height with body weight was $0.88,0.73$ and 0.72 , respectively. Meanwhile, Okpeku et al. (2011) reported $0.90 \mathrm{R}^{2}$ West African Dwarf goat for the relationship between chest circumference and body length to body weight.

\section{Estimating body weight based on body morphological size}

The determination of body weight of beef cattle was done in two ways, direct weighing (weight scale) and estimating the weight based on some measuring results of body morphology that influenced the body weight (Gunawan et al.. 2008). Real weighing was difficult because of the heavy equipments but accurate result was obtained. On the contrary, estimating body weight result was not as precise as direct weighing, it could be under or over estimates.

Measuring results on the right part of the body would result in relatively low deviation in body weight prediction and closer to the real measurement. With the development of mathematical relationship, it is possible to estimate the body weight quite accurately (Wilson et al., 1997). Permatasari et al. (2013) stated that several studies showing linear body size could be used to estimate the animal's body weight. Apriliyani (2007) reported that body length, chest circumference and hip circumference were the most effective to estimate body weight. The high correlation between the chest circumference and the body weight was caused by weight gain. It would be followed by the growing size of the musculus serratus ventralis and musculus pectoralis located around chest area so that the size of chest circumference increased (Badriyah. 2014). Kadarsih (2003) stated that the body length had $84 \%$ role of body weight gain of Bali cow. 
Furthermore, Fajemilehin and Salako (2008) gave a conclusion on their result that the body morphological size of the animal, such as : chest circumference, body length, width and height of the waist could be used as an instrument to estimate the body weight. Meanwhile, Getachew in Musa et al. (2012) stated that the body weight could be predicted by some parts of the body that needed the program of breeding and production. The predicted data of the body weight measurement of PO steers and heifers are presented in Table 4.

The prediction mean of body weight PO steers referred to four results of body morphology measurement ( $\mathrm{BL}, \mathrm{CC}, \mathrm{BH}, \mathrm{HH})$, it used mathemetical formula, i.e: $Y=-514.215+$ $2.545 \mathrm{BL}+2.117 \mathrm{CC}+(-1.758 \mathrm{BH})+2.684 \mathrm{HH}$; while the two measurement of body morphology ( $\mathrm{BL}$ and $\mathrm{CC}$ ) used mathematic formula, i.e: $Y=-514.215+2.545 B L+2.117 C C$ with the coefficient of determination $\left(R^{2}\right)$ of $92.70 \%$. Estimating the mean weight of PO heifers was based on four results of body morphology measurement using mathematic formulation, i.e: $Y=-512.760+2.160 \mathrm{BL}+$ $2.560 \mathrm{CC}+(-2.030 \mathrm{BH})+2.740 \mathrm{HH}$ and according to two body morphology measurement results. it used mathematical formula, i.e: $\mathrm{Y}=-512.760$ $+2.160 \mathrm{BL}+2.560 \mathrm{CC}$ with $\mathrm{R}^{2}$ of $86.80 \%$.

The mean of body weight of PO steers used two measurements results ( $\mathrm{BL}$ and $\mathrm{CC}$ ) which were closer to the real weighing than four measurements of body morphological size (Table 4). This phenomenon indicated that body length and chest circumference had high relationship with body weight on PO steers. Meanwhile, PO heifers showed different results where the estimation of average body weight using four measurements of body morphological size was closer to the real weighing results.

The estimate of PO heifer body weight was similar to Wirdateti et al. (2009), the use of independent variables to estimate the body weight causing the higher accuracy. Meanwhile. by estimating the body weight measurement of PO steers based on two body morphological size it made closer to the real weighing. It could be proven on variable of body height and chest circumference less significant to the body weight but positively correlated to increasing of cattle's age. Anggraeni and Triwulaningsih (2007) reported similar results on buffaloes; according to value of the determintaing analysis

Table 3. The regression equation in PO steers and heifers

\begin{tabular}{|c|c|c|c|}
\hline \multirow{2}{*}{ Sex } & \multirow{2}{*}{ Regression equation } & \multicolumn{2}{|c|}{ Analysis } \\
\hline & & Double correlation (R) & Determination $\left(\mathrm{R}^{2}\right)$ \\
\hline & $Y=-514.215+2.545 B L+$ & & \\
\hline \multirow[t]{3}{*}{ Steer } & $2.117 \mathrm{CC}+(-1.758 \mathrm{BH})+$ & 0.963 & 0.927 \\
\hline & $2.684 \mathrm{HH}$ & & \\
\hline & $Y=-512.760+2.160 B L+$ & & \\
\hline \multirow[t]{2}{*}{ Heifer } & $2.560 \mathrm{CC}+(-2.030 \mathrm{BH})+$ & 0.932 & 0.868 \\
\hline & $2.740 \mathrm{HH}$ & & \\
\hline
\end{tabular}

Table 4. The mean of the real weighing and estimation of PO steers and heifers

\begin{tabular}{lcccccc}
\hline & \multicolumn{3}{c}{ Mean of body weight } & \multicolumn{4}{c}{ The prediction mean of body weight } \\
\cline { 2 - 7 } Sex & Real & SD & $\begin{array}{c}\text { four body } \\
\text { morphological } \\
\text { size* }\end{array}$ & SD & $\begin{array}{c}\text { two body } \\
\text { morphological } \\
\text { size ** }\end{array}$ & SD \\
\hline Steer & 223.71 & \pm 46.13 & 227.87 & \pm 51.04 & 223.71 & \pm 43.97 \\
Heifer & 225.35 & \pm 34.42 & 225.38 & \pm 35.05 & 223.48 & \pm 30.65 \\
\hline
\end{tabular}

$*$ = Body length. chest circumference. body height. hip height;

** = Body length. chest circumference; SD = standart deviation 
$\left(R^{2}\right)$ of linear equations developed by chest circumference and body length. the best accuracy as a predictor of body weight with $\mathrm{R}^{2}$ was $68.70 \%$ and $48.20 \%$. respectively; while the body height and hip height had a low determinating value from $9.9 \%$ to $13.3 \%$.

\section{Conclusion}

The body length and chest circumference gave positive effect on body weight gain of either PO steers or heifers with significant value of 0.002 and 0.011 , and 0.004 and 0.00, respectively. The estimation of PO heifer body weight approached the real weighing from four body morphological size (body length. chest circumference. body height and hip height). Meanwhile. PO steers used two body morphological size (chest circumference and body length) and the result close to the real weighing values.

\section{References}

Abdullah MAN, RR Noor, H Martojo, DD Solihin and E Handiwirawan. 2006. The Phenotypic Variability of Aceh Cattle in Nangroe Aceh Darussalam. J. Indon. Trop. Anim. Agric. 32(1): 11-21.

Anggraeni A and E Triwulaningsih. 2007. The performance of body weight and body morphometrics of Sumbawa buffaloes selected for fattening. Proceeding of National Seminar and Workshop on Buffaloes Farming. (In Indonesia).

Direktorat Jenderal Peternakan. 2008. Populasi Sapi Potong. Direktorat Jenderal Peternakan. http://www.deptan.go.id. (accessed: Dec, 2012).

Litbang Deptan. 2011. Potensi Keragaman Sumber Daya Genetik Sapi. http://peternakan. litbang.deptan.go.id. (accessed: 8 March 2013).

Apriliyani IN. 2007. Production performance and estimation of live weight based on linear measures of local and crossed cattle. Undergraduate Final Report. Bogor Agricultural University. (In Indonesia).

Aryogi, Sumadi and W Hardjosubroto. 2005. Performance of Ongole-crossed cattle in low land area (Case study in Kota Anyar Sub-district of Probolinggo District, East Java). Proceeding of National Seminar on Technology and Veterinary of Livestock Farming, p.98-104. Centre of Research and Development of Livestock Farming. Bogor. (In Indonesia).

Badriyah N. 2014. Kesesuaian rumus schoorl terhadap bobot badan sapi Peranakan Ongole (PO) (Precision of Schoorl formula on body weight of Ongole-crossed cattle). Jurnal Eksakta. 12(2): 99-103. (In Indonesia).

Burnham DL. RW Purdeas and ST Morris. 2000. The relationship between growth performance and feed intake bulls and streers at pasture. AsianAus. J. Anim. Sci. 13: 165.

Chadijah St. 2012.The Effect of Age and Sex on Body Weight Gain of Bali Cattle. Scientific Article Cattle Production. Pp:1-7.

Dalton DC. 1980. An Introduction to Practical Animal Breeding. Granada. London. 176 pages

Fajemilehin OKS and AE Salako. 2008. Body measurenment characteristics of the West American Dwarf (WAD) goat in deciduous forest zone of Southwestern Nigeria. Africa. J. of Biotech. 7(14): 2521-2526.

Gunawan A. K Jamal and C. Sumantri. 2008. Body Weight Estimation Through Morphometric with the Best Subset Regression Approach on Agile Garut Lamb and the Cross Breed. Animal Scientific Magazine. 11(1):1-6.

Hanibal MV. 2008. Size, Shape and Estimation of Body Weight Based On Body Measurement of local crossbred male Garut Lamb in Tasikmalaya Regency. Undergraduate Thesis. Animal Science Faculty. Institut Pertanian Bogor. Bogor.

Hartati. Sumadi and T Hartatik. 2009. Identification of Genetic Characteristics of PO cattle in Smallholder Farming. Buletin Peternakan. 33(2): 64-73.

Kadarsih S. 2003. The role of Body Measurement on Body Weight of Bali Cattle in Bengkulu Province. Jurnal penelitian UNIB. IX (1) : 45-48.

Kay $M$ and R Housseman. 1975. The Influence of Sex on Meat Production. In: Meat. Cook DJ. Lawrrie RA (Ed). London. Butterworth.

Musa AM. NZ Idam and KM Elamin. 2012. Regression analysis of linier body measurements on live weight in Sudanese Shugor sheep. Online J. Anim. Feed Res. 2(1): 27-29.

Okpeku M. A Yakubu. SO Peters. MO Ozoje. CON Ikeobi. OA Adebambo and IG Imumorin. 2011. Application of multivariate principal component analysis to morphological characterization of indogenous goats in Southern Nigeria. Acta Agriculture Slovenica. 98 (2): 101-109.

Otoikhian CSO. AM Otoikhian. OP Akporhuarho. VE Oyefia and CE Isidahomen. 2008. Body measurement parameters as a function of assessing body weight in goats under on-farm 
research environment. Afr. J. Gen. Agric. 4 (3): 135-140.

Parakkasi. A. 1999. Ilmu Makanan Ternak Ruminansia. UI Press. Jakarta. Pp: 371-374.

Permatasari T. E Kurnianto and E Purbowati. 2013. Relationship between Body measurements and Body Weight ofKacang Goat in Grobogan Regency, Central Java. Animal Agric. J. 2(1): 2834.

Rachma S. RMT Agus and L Rahim. 2009. The breadth of Vertebrae sacrum, vertebrae thoracalis, Ethmoidale breadth and Vertebrae Sacrum and Ethmoidale Length to estimate Body Weight of Bali Cattle.. J. Sains dan Teknologi. (9): 119-124

Sarbaini. 2004. Study of External Characteristics Diversity and DNA Microsatelite of Coastal Cattle in West Sumatra. Disertation. Graduate School. Bogor Agriculture Institute. (in Indonesian with abstract in english)

Sugiyono. 2007. Memahami Penelitian Kualitatif. Alfabeta. Bandung. 338 pages.

Tadesse A. T Gebremariam and SK Gangwar. 2012. Application of linear body measurements for predicting body weight of Abergelle goat breed in Tigray region. Nothern-Ethiopia. Global J. of Bio-Sci. and Biotech. 2 (2): 314-319.

Warwick EJ. JM Astutik and W Hardjosubroto. 1983. Pemuliaan Ternak. Gadjah Mada University Press. Yogyakarta.

Wijono DB. Mariyono and E Romjali. 2006. The effect of season on the growth of Ongole-crossed beef cattle. In: Proceeding of National Seminar on Veterinary and Livestock Farming. Bogor. 5-6 September 2006. HIm. 183 - 186. (In Indonesia).

Wijono DB. Hartati and DM Dikman. 2007. Correlation between Linear Body Measurement of Weaned Cattle with The Changing Live Weight of Mature PO Cattle. In: Proceedings of Seminar Nasional Teknologi Peternakan dan Veteriner 2007. Bogor. 21-22 August 2007. HIm. 236-239. (In Indonesian with abstract in English)

Wilson LL. CL Egan and TL Terosky. 1997. Body measurements and body weights of special-Fried Holstein veal calves. J. Dairy Sci. 80: 3077 - 3082.

Wirdateti. B Brahmanto. A Reksodiharjo. G Semiadi and H Dahruddin. 2009. Morphometric Characteristics of Sumbar Deer (Unicolor Deer) as the Basic Criteria of Natural Growth Selection. J. Veteriner (10): 7-11. 